\title{
Development of Education Quality: A Study of the Education Operational Assistance Program in Southeast Sulawesi
}

\author{
Edy Karno $^{1}$, Syahrul ${ }^{2}$, Badarwan $^{3}$ \\ \{edykarno72@gmail.com¹, syahrul.stain@gmail.com² ${ }^{2}$ badarwan.kdi@gmail.com³ \\ Universitas Halu Oleo, Indonesia ${ }^{1}$ \\ Institut Agama Islam Negeri Kendari, Indonesia ${ }^{2,3}$
}

\begin{abstract}
This study aims to achieve three main objectives: 1) to provide an overview of BOP in Southeast Sulawesi; 2) to map out the impact of the Education Operational Costs program on improving the quality of education; 3 ) to obtain information on the weakness of the Education Operational Cost (BOP) program. This study uses a qualitative approach. The results of the study established: 1) Management of Education Operational Costs of Education in Southeast Sulawesi was implemented in stages, from provincial, to district/city, and school level; 2) The impact of BOP support for schools include: increasing the number of students attending and graduating each academic year, improving the quality of educators and provision of educational facilities, increasing school participation in academic activities and community participation; 3 ) The weaknesses of the BOP program in Southeast Sulawesi revolve around the procurement and distribution of educational tools that do not meet school needs.
\end{abstract}

Keywords: Quality, Education Operating Costs, Local Government

\section{Introduction}

The Education Operational Cost (BOP) Program at Secondary Education level is a Southeast Sulawesi provincial government program founded in 2013 that puts resource quality at the forefront of regional development. The program is implemented in order to support the declaration of 12-year compulsory education.

BOP funding is calculated according to the number of students and the number of study groups to help meet non-personnel school operating costs.

With the goal of supporting students, schools are required to assist low-income students with the obligation of paying school fees and expenses for extracurricular activities using BOP funding. Students who are exempt or get a tuition fee is based on the number of low-income students, the BOP funds received and the tuition fees.

This study aims to provide an overview of Operational Cost Management (BOP) during 2012-2014 in Southeast Sulawesi; map out the impact of the Education Operational Costs program on improving the quality of education; and obtain information on the weakness of the BOP program. 


\section{Method}

This research uses a qualitative approach with the multi-site method to provide in-depth information about the operational cost of education programs at the SMA/SMK level in Southeast Sulawesi. The multi-site method is used in the framework of effectiveness and efficiency of research implementation, in which the researcher establishes several vocational high schools which are the icons in each district as subject/study object.

Based on the above, the study population would usually be all high school/vocational schools that have received project assistance spread over five districts in Southeast Sulawesi. However, due to the limitations of time and area coverage, the study was conducted in only 4 urban and outer city schools that can represent SMA/SMK. The five selected districts / cities are: 1) Bau-Bau, 2) Kolaka, 3) North Kolaka, 4) Konawe, and 5) Kendari.

Data and information gathering were executed through in-depth interview techniques and analysis of the BOP Sultra program. Aspects under investigation included: 1) BOP funding for managers at district/municipality level. Questions arose regarding the duties and responsibilities of BOP fund managers. 2) BOP funding for school management, including the principle, teaching staff and treasurer, as well as the School Committee. What are the duties and responsibilities of BOP managers at school? 3) The level of quality for school culture funded by the BOP, which includes teacher education and training, procurement of textbooks and educational equipment, curriculum management, instructional innovation, organizing competitions and extra-curricular activities. 4) Impact relevance of BOP Program.

The collected data is thoroughly analyzed to draw the most accurate conclusions. The data was tested by means of trianggulasi, member check and increasing persistence of observation in order to guarantee validity.

\section{Research Findings and Discussion}

BOP management organizations are formed in stages, beginning with the provincial/district level that serves to implement BOP programs up to the target set. The organization at the provincial level is referred to as the Technical Team for Provincial Education Operational Assistance Activities, abbreviated with the Provincial BOP TTK, domiciled in the Provincial Education Office. At City level, this is called TTK BOP Kabupaten/Kota and is domiciled in City Education Office.

BOP managers at the school level are principals, teachers, treasurers and school committees. The responsibilities of the BOP recipients are set out in the technical manual (Juknis) issued by the Department of Education and Culture of Southeast Sulawesi Province. However, in the implementation of BOP for the period of 2012-2014, it was found to be ineffective in terms of procurement and distribution of books and educational equipment. The schools this study was sampling stated that the mechanisms for procuring the needs of books and educational equipment in BOP proposals did not at all fit with the books/apparatus required. This is due to the procedure being completed by the Provincial Education Department through a tender system in accordance with applicable legislation. 
Table 1 suggests that the increase in students every year at each district/city, is not proportional to the amount of BOP funds received, both with SMA/SMK city and outer city schools (see Table 2). BOP funding is calculated by the number of students and the number of study groups, which therefore implies that if the number of students increases, the BOP funds used to help schools meet the non-personnel school operating costs also increase.

Qualitatively, the improvement of SMA/SMK in Southeast Sulawesi is marked by the increasing quality of teachers, which is observed by the number of teaching staff attending relevant training. However, assessing the quality of education via the number of teachers who have attended the educational program during the last three years is an indirect impact of the BOP program in schools. Teachers generally make use of the scholarship programs available at district, provincial and national levels to improve their educational qualifications.

The procurement of educational facilities suggests an improvement based on the increased number of books and educational equipment ordered by the sample schools, unfortunately some of the books and educational support facilities were not always in accordance with the needs of the school.

Quantitatively, an increase in the quality of education is shown by the increased number of graduations and value of UAN, as well as active and successful participation of schools in academic, art and sport competitions.

In terms of community participation, schools have actively involved parents in the preparation of school program plans over the last three years. In this case, there is participation by School Based Management (MBS) involving communities who are recruited in school committees. Parent take involvement in preparing school program plans and various school quality improvement programs in the form of parent organizations called "School Committee". This committee, in conjunction with the school, provide better solutions in improving the quality of education, parents are increasingly more aware of the importance of their participation and cooperation..

\section{Conclusions and Recommendations}

Based on the results and discussion of the previous findings, the following conclusions can be summarized as follows: Management of Education Operational Costs of Education in Southeast Sulawesi is implemented in stages, from provincial, district/city, to school level. The responsibilities of BOP recipients are regulated through technical guidance issued by the Department of Education and Culture of Southeast Sulawesi Province. Furthermore, BOP support encourages an increase in the number of students attending and graduating each academic year, an improvement of the quality of teachers and educational facilities, an increase of school participation in academic activities as well as community participation in activities. The weaknesses of the BOP program in Southeast Sulawesi include the distribution of educational tools that are not based on the needs of the school, the implementation of the tender mechanism in the procurement of educational infrastructure facilities, and the increase in the number of students not being directly proportional to the school BOP acceptance. 
As a result of this study, several recommendations are proposed as follows: 1) BOP management mechanisms at provincial, district/municipality and school levels need to be implemented in accordance with established implementation procedures (Juknis BOP). In this case, a monitoring mechanism is required at each level of BOP managers. 2) Scheduled monitoring and evaluation will reduce the irregularities in the implementation of BOP management at all levels. The most effective supervision is via the respective School Committees. Several schools observed indicated poor supervision of the management of BOP funds. If School Committees are empowered, then irregularities in the management of these BOP funds can be minimized. 3) BOP Technical Guidelines for secondary education needs to be revised, especially on the regulatory aspects of BOP procurement and distribution mechanisms. The mechanism for the procurement of books and other educational equipment should be carried out by the BOP sponsoring school through a tender process mechanism in accordance with the provisions of the legislation governing the tender process. This is so that the school can easily control the third party who held a reference book and educational equipment so that books and equipment is in accordance with the needs of the school.

\section{References}

[1]Dunn, William N.: Public Policy Analysis. Routledge (2015)

[2] Stewart Jr, Joseph, David Hedge, and James P. Lester: Public policy: An evolutionary approach. Nelson Education (2007)

[3] E. Karno, "The Evaluation Of Cerdas Sultraku Program in Southeast Sulawesi," 05-Jan-2019. [Online]. Available: osf.io/rkdfw.

[4]Sugiyono: Metode Penelitian Kuantitatif, Kualitatif dan R\&D. Bandung, Alfabeta (2010)

[5]Dinas Pendidikan dan Kebudayaan Provinsi Sulawesi Tenggara: Petunjuk Teknis Biaya Operasional Pendidikan Jenjang Sekolah Menengah (2011)

[6]Dinas Pendidikan dan Kebudayaan Provinsi Sulawesi Tenggara: Petunjuk Teknis Biaya Operasional Pendidikan Jenjang Sekolah Menengah (2014) 